\title{
THE FIRST AMENDNIENT AND CIVIL DISABILITIES IMPOSED UPON ATHEISTS
}

\author{
By Charles E. Ruseing:
}

The more apparent problems raised by the Everson, ${ }^{1} \mathrm{McCol}$ lum, ${ }^{2}$ and Zorach ${ }^{3}$ cases have received extended discussion. ${ }^{4}$ But the tenor of the opinions suggest another question: What is the position of the atheist in relation to the First Amendment's provision: "Congress [and the states through the Fourteenth Amendment] shall make no law respecting an establishment of religion, or prohibiting the free exercise thereof; ...."? Some states still impose civil disabilities upon religious non-believers. This comment is a survey of these disabilities ${ }^{5}$ and a consideration of the First Amendment's protection of atheists in light of the Everson, McCollum, and Zorach decisions.

These disabilities occur chiefly in the following areas: (1) atheists have been held to be incompetent as witnesses, or the credibility of their testimony is subject to impeachment; (2) they have been declared incompetent as jurors; (3) the validity of their dying declarations has been subject to impeachment; and (4) they have been denied the right to hold public office because of their irreligion. ${ }^{6}$

* 2nd year law student, Duke University.

1 Everson v. Board of Education, 330 U. S. 1 (1947).

2 Illinois ex rel. MeCollum v. Board of Edueation, 333 U. S. 203 (1948).

${ }^{3}$ Zorach v. Clauson, 343 U. S. 306 (1952).

- JoHNson and Yost, Separation of ChuRch and STATE IN tree UNTted States (1948); Parsons, The First Freedon: Considerations on Church and State in the Untted States (1948); Ransswant, The UntTed States of Aarerica: A SecUlar STATE; How IT Was BUILT aNd How IT Works (Bangalore, 1949); Symposium on Religion and the State, 14 LaW and ConTrearP. PROB. 1-159 (1949); Paulsen, State Constitutions, State Courts, and First Amendment Freedoms, 4 VAND. L. REV. 620 (1951); Pfeffer, Church and State; Something Less Than Separation, 19 U. OF CHr. I. Rev. 1 (1951).

¿ See generally: Swancara, OBStruction of JUSTice BY Retiaton (1936);

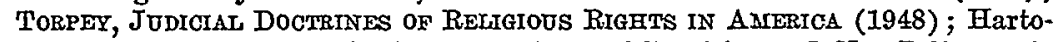
gensis, Denial of Equal Rights to Religious Minorities and Non-Believers in the United States, 39 Y ALE L. J. 659 (1930); Pfeffer, op. cit. supra, note 4.

- An effort has been made to eite and diseuss only the most recent eases in each jurisdiction. 


\section{The Atheist as a Witness}

When the witness steps into the box, and before he testifies, he must take an oath which usually concludes with "So help me God." By so swearing to God, the witness promises God he will speak the truth. If the witness lies divine retribution will be wreaked, not simply because the witness spoke an untruth, but because he has broken his promise to God. This was the theory of the oath as it developed in English law from early times. ${ }^{7}$ When a person takes the oath it is an indication to the court that he acknowledges his responsibility to God. From such a theory the common-law held that one who did not believe in God, or one who believed in God, but denied the sureness of divine punishment was incompetent to testify in a court of law. ${ }^{8}$ The common-law associated not only untruthfulness but general moral turpitude with religious nonbelievers.

Today, in Great Britain, although the Church of England is the established Chureh, persons with all shades of belief and disbelief are admitted to office, allowed to testify, and to make "oaths" and make affidavits. ${ }^{9}$

Early American decisions followed the early English doctrine, and atheists were not allowed to testify because of thcir denial of God and ultimate divine punishment. Eventually, most religious disqualifications relating to testimonial competency were abrogated, and it became generally realized that

"The true purpose of the oath is not to exclude any com. petent witness, but merely to add a stimulus to truthfulness wherever such a stimulus is feasible. . . . It came gradually

${ }^{7} 6$ Wigarore, Evidence, $\$ 1816-1817$ (3rd ed. 1940); 1 Greanlenf, EiviDENCE, $\$ 364$ a (16th ed. 1899).

${ }^{8}$ First most explicitly set out in the famous case of Omichund v. Barker, 1 Atk. 21, 26 Eng. Rep. 15; Willes 538, 125 Eng. Rep. 1310 (1744). There aro two reports of this case: one in 1 Atkyns and one in Willes, the first laying down the rule that a witness must believe in God and future punishment, and the second (believed to be the correct report by Wigmore and others) laying down the rule that a witness must believe in a God and in present or futuro punishment.

${ }^{\circ} 1$ and 2 VICT. c. 105-British Oaths Act of 1888, 51 and 52 VIcT. c. 46 : "Every person upon objecting to being sworn and stating, as the ground of such objection, ... that he has no religious belief ..., shall be pormitted to make his solemn affirmation instead of taking an oath. ..." Quote in Hartogensis, Denial of Equal Rights to Religious Minorities and Non-Believers in the United States, 39 YALE I. J. 659, 669 (1930). 
to be perceived that the use of the oath, not to increase testimonial efficiency, but to exclude qualified witnesses, was not only an abuse of its true principle, but also practical injustice to suitors who need such testimony. ..., pio

Professor Wigmore summarizes the state of American law today on the subject, as follows:

". .. (2) In almost every jurisdiction the rigor, and injustice of the common-law rule has been removed, for persons have an incompatible theological belief, in one of two ways:

(a) In all but a few jurisdictions (e.g. Oklahoma, Virginia) a statute allows the witnesis to choose to make affirmation instead of oath. This choice is usually provided for those who lack the requisite belief, and for those who may have the belief but are forbidden by conscientious scruples [to take the oath]....

(b) ... under constitutional (rarely statutory) provisions guaranteeing that theological belief shall not affect one's civil capacities (or, specifically, one's competency as a witness). These provisions are almost universal; in only three jurisdictions (Arkansas, Maryland, North Carolina) is a theological belief expressly declared necessary. By usual construction, the result of this legislation has been to allow the administration of the oath to persons, ... lacking the common-law belief. The singular result is that relief is afforded, not in the natural way, by substituting affirmation for oath, but in an evasive way, by preserving an invocation which has no meaning for the witness and by thus reducing the oath to an empty formula.

"In a few jurisdictions where the Constitution, in such an article, expressly saves all oaths and affirmations, it is clear that the oath ought to remain, as to the requisite belief, precisely what it was at common-law, but under such Constitutions, nevertheless, the witness' right to make affirmation instead of oath should be with equal certainty guaranteed."

Only two states are found which have constitutional provisions disqualifying atheistic witnesses. ${ }^{12}$

${ }^{10} 6$ Wianore, Etidence, 1827 (3rd ed. 1940).

11 Id. $\$ 1828$.

12 Arkansas Const., Art. 19, \$1. Mueller v. Coffman, 132 Ark. 45, 200 S. W. 136 (1918) ; Farrell v. State, 111 Ark. 180, 163 S. W. 768 (1914). (Both cases upholding the competency of the challenged witnesses.) MarYLAND CoNst,, Declar, of Rights, Art. 36 (1867). DuPuy v. Transportation and Terminal Co., 82 Mrd. 408, 34 AtI. 910 (1896). (Evidently disqualifying "atheist's"' testimony.) Arnd v. Amling, 53 Md. 192 (1879). (Allowing impeachment, but refusing to disqualify when witness answered affirmatively court's questions of his belief in God and divine punishment.) 
The remainder of the states that disallow testimony by religious non-believers do so through case law. ${ }^{13}$

In State $\nabla$. Levine, ${ }^{14}$ the New Jersey court made a historical examination of state statutes relating to religious qualifications for witnesses. One such statute, prescribing oaths for witnesses, allowed those "conscientiously scrupulous" against taking oaths to make affirmation instead. The court found that with respect to witnesses, not party to cause, the legislature intended that the exception to the oath should apply only to witnesses who have religious scruples conscientiously founded upon religious beliefs embracing belief in deity. Such a finding disqualified several defense witnesses who were religious non-believers.

But the court found contrary legislative intent as regards the defendant who had been convicted for advocating the subversion of the government of the United States, and who was also an atheist. The court held that since he was a party to cause, he should have been allowed to testify under affirmation, and the trial court's allowing him to "speak" before the court without making him a "witness" was reversible error.

The court found, that with respect to the defendant, that Sec. 57 of the Criminal Procedure Act ${ }^{15}$ set up a civil right. To exclude his testimony, the court went on to say, would be in contravention of the Fourteenth Amendment of the Federal Constitution, and exclusion on account of the defendant's religious principles would be in contravention of Article 1, section 4, of the state constitution. ${ }^{10}$

The disqualification of atheistic witnesses, not parties to cause, was not a deprivation of a civil right, so the court found. For the witness, not a party, without an interest, has no right in himself

${ }^{13}$ Detatware: Perry v. Steward, 2 Har. 37 (Del: 1835). New HaArpshire: Norton v. Ladd, 4 N. H. 444 (1828). NEW JERSEX: State v. Lovino, 109 N. J. L. 503, 162 Atl. 900 (1932). Query: see discussion following in text. North Carolina: Shaw v. Moore, 49 N. C. 25 (1856); State v. Beal, 199 N. C. 278, 154 S. E. 604 (1930). Query: see discussion following in text. Sourr Carolina: State v. Abercrombie, 130 S. C. 358,126 S. E. 142 (1925). Although the court pnt exclusion on the ground of lack of religious belief, one might suspect that the disqualification of the eight-year-old boy was really based on his immaturity, and his probable nndeveloped distinction between good and evil.

14109 N. J. I. 503, 162 Atl. 909 (1932).

15 6... npon the trial of any indictment the defendant shall be admitted to testify if he shall offer himself as a witness. PAMrr. I. 1898, cl. 237, p. $866 ; 2$ CoMP. STAT., p. 1820."' (N. J.)

is "'No person shall be denied the onjoymont of any civil right merely on account of his religious principles; ...." 
to testify. "The inability of a party to procure testimony from an unbeliever is not the denial of the equal protection of the laws nor is it the denial of a civil right because of the party's religious principles. That inability rests equally on a party that is a believer as on one that is not."17

The position of the atheist witness in North Carolina appears to be somewhat unsettled. As early as 1856, that state's Supreme Court used words of remarkable liberality about a subject to which liberality came late to many states. ${ }^{18}$ In 1930 , the question arose again in State $\nabla$. Beal. ${ }^{19}$ In that case the witness had not been challenged upon her voir dire to test her competency, and had been sworn to speak the truth. She was then questioned upon crossexamination by the solicitor as to her religious beliefs for the purpose of impeaching her credibility. The court held that such questioning, if error, is not prejudicial when answers of the witness, taken in connection with previous testimony, did not show that she intended to express a disqualifying disbelief. A change in the state constitution ${ }^{20}$ was observed and discussed, but the effect of the change was not determined. ${ }^{21}$

17 109 N. J. I. 503, 509, 162 Atl. 909, 910 (1932).

18 The court held that one who believes in the existence of a Supreme Being who will punish in this world for every sin committed-but does not believe that punishment will be inflicted in the world to come-is a.competent witness. The court observed: "It was said in the argument 'to be sworn as a witness is no privilege-the person loses nothing by being incompetent.' This is a narrow view of this questiou. If he be held incompetent as a witness on the ground that he cannot take an oath, it follows that he cannot swear to a book account. If an injunction is obtained, it must be made perpetual, because he cannot swear to his answer; nay, more, he cannot take the oath of office...; in short, it would be the institution of a 'test oath,' towards which our revolutionary fathers had so just an abhorrence, and which is wholly repugnant to the tolerant and enlightened spirit of onr institutions and of our age in which we live." Shaw v. Moore, 49 N. C. 24, 31 (1856).

10199 N. C. 278,154 S. E. 604 (1930).

${ }^{20}$ N. C. CoNst., Declar. of Rights, $\$ 19$ (1776): "That all men have a natural and unalienable right to worship Almighty God according to the dictates of their own conseience."

N. G. CoNST., \& 26 (1868) : adding “"..., and no human authority should in any case whatever, control or interfere with rights of conscience."

21 "Wo are not now called upon to say, nor do we decide, what effect, if any, this change in the organic law had upon the then existing disqualification of witnesses, or upon the right of the Legislature thereafter to render persons incompetent to testify as witnesses, on account of their opinions on matters of religious belief. Nor do we find any case, heretofore decided, dealing with the effect of this change. State v. Pitt, 166 N. C. 268,30 S. E. 1060; Lanier v. Bryan, 184 N. C. 235 , 114 S. E. 6."' State v. Beal, 199 N. C. 278, 300, 154 S. E. $604,616(1930)$. 
The observations of the court on the power of the state to disqualify or impeach the credibility of an atheistic witness are pertinent enough to reproduce at some length :

". . For some reason, too deep to fathom, men contend more furiously over the road to heaven which they cannot see, than over their visible walks on earth; and it is with these visible walks on earth alone that we are concerned in the trial of causes. In recognition of this fact and because 'our civil rights have no dependence on our religious opinion,' as proclaimed by Thomas Jefferson and embodied in the Virginia statute of religious freedom, it was provided in the North Carolina Constitution of 1868 that 'no human authority should in any case whatever, control or interfere with the rights of conscience." "22

As to the impeachment of credibility:

"... [I]t may be queried that, if one's religious belief or unbelief is not to affect his competency as a witness, but may be inquired of to affect his credibility, have not his rights of conscience, for all practical purposes been affirmed and denied in the same breath? What boots it, ask the advocates of this view, whether he be refused the right to testify altogether, or being permitted to testify, have his testimony discredited and rejected by the jury, if in the end they both amount to the same thing? In this counection, it is contended that there is no essential difference between a refusal to hear and a rejection after hearing [citing cases]. . . , ${ }^{23}$

The Court quoted Justice Brewer's language in Church of the Holy Trinity v. United States :24 "Ours is a religious people," and queried:

". . . Is it an interference with the rights of conscience, or an effort to control such rights (prohibited by,our Constitution), to interrogate a witness about his opinions on matters of religious belief? It is not proposed to change his opinions or disturb them in any way. It is only sought to discover what opinions he entertains-those of his own choosing-so as to enable the jury, as far as such indications will allow, to know what manner of thoughts he is thinking at the time he testifies. It has been said that a man is what he thinks, 'For as he thinketh in his heart, so is he.' Prov. $23: 7 . " 25$

${ }^{22} I d ., 199$ N. C. 278,302 et seq., 154 S. Ð. 604,618 (1930).

${ }^{23} 1 d ., 199$ N. C. $278,302,154$ S. E. 604,617 (1930).

${ }_{24} 143$ U. S. 457 (1891).

${ }^{25}$ Supra, note 21, 199 N. C. 278, 301, 154 S. E. 604, 617 (1930). 
And in 1932, the North Carolina court replied, when plaintiff alleged-in a suit for alienation of affection-that defendant had attacked the church and the marriage ceremony sanctioned by the church, that

"The liberality of our Constitution and laws not only - recognizes but guarantees to each man the right to construct a religious belief to suit himself, free from the supervision and control of any power on earth. Moreover, the same liberality and security stand, guard about him even if he has not religion at all. These principles are too fundamental to require debate or elaboration. State $\nabla$. Beal 199 N. C. 278, 154 S. E. 604." (Emphasis added.) ${ }^{26}$

For a state that is usually listed as one of the classical examples of the preservation of the common-law religious requirements for competency as a witness the language of the above decisions seems almost radical. It is more than questionable whether a witness' credibility may not still be attacked on grounds of irreligion in that state. On the other hand, it would appear certain that the North Carolina court would overrule any attempt to disqualify a witness on solely atheistic grounds if a case were squarely presented.

The purpose of this extended discussion of one jurisdiction is to indicate that parallel thought may exist in other states. Evidently, North Carolina is the only state which has given recent lengthy consideration to the problem. But other states, which ostensibly exclude atheistic testimony, might repudiate exclusion today.

The Federal Courts would apparently admit the testimony of atheists in both criminal and civii actions. ${ }^{27}$

For the religious person the use of the oath is useful to remind him of the solemnity of his undertaking, and his "promise to God" calls to mind the obligation of truthfulness. But as a device to prevent perjury, the applicability of the oath is more questionable. The shrewd perjurer-professing religion or not-would keep silent about any atheistic leaning he might have and hotly deny any allegations of irreligion. Professor Wigmore vigorously denies the propriety of admission of any evidence which would impeach testimonial capacity on atheistic grounds. ${ }^{28}$

${ }^{26}$ Hankins v. Hankins, 202 N. C. 358, 162 S. E. 766 (1932).

"7 Gillars v. United States, 182 F. $2 d 962$ (D. C. Cir. 1950). (Allowing atheist to testify on affirmation in criminal prosecution.)

Concerning eivil actions: Fen. R. Grv. P. 43 (a) (d). (28 U. S. C. A. 1950).

28 "Much less in these days should evidence be admitted ... of mere disbelief in a personal Deity, i.e. atheism,-a belief quite consistent with the strict- 
Once a witness has been admitted to the stand, to what extent may opposing counsel discredit the veracity of his testimony by showing religious unbelief? Most states would rule such crossexamination out of order as prejudicing the jury against the witness, or as being irrelevant to the determination of the witness's truthfulness. ${ }^{29}$

Some states still preserve inquiry into religious belief to determine credibility. Such preservation is almost invariably accomplished by statute; either by direct provision, ${ }^{30}$ or indirectly, by providing that eommon-law incompetency can still be used to affect credibility. ${ }^{31}$

Most comments applicable to the "reasonableness" of disqualifying witnesses because of religious belief would seem pertinent in

est sense of moral obligation to speak the truth. Some statutes, however, proserve a permission to use such evidence,-a sop of mediaevalism left to satisfy those who would otherwise not have consented to abolish theological qualifications for the oath. But some Courts and Constitutions justly reject evon this much of theologic heterodoxy." 3 Wrarrone, Eridence $\$ 936$ (3rd ed. 1940).

29 "No question should ... be allowed and its answer compelled for the purpose of discrediting the witness unless the fact which the question seeks to elicit has an inherent or obvious teudency by general consensus of opinion among civilized people to make the witness, in the eyes of honest and rightthinking men, less likely to tell the truth. The mere non-belief in God doos not measure up to this standard." MeClellan v. Owens, 335 Mo. 884, 889, 74 S. W. $2 d 570,578$ (1934).

${ }^{30}$ Grorala Code, \$ 38-1602 (1933). Eugee v. State, 159 Ga. 604, 126 S. E. 471 (1925); Gantz v. State, 18 Ga. App. 154, 88 S. E. 993 (1916). IndinN, BuRns Stats., \$2-1725 (1933). Snyder v. Nations, 5 Blackf. 295 (Ind. 1840). Matne Rev. Stats., c. 100, $\$ 114$ (1944). Massachusetris ANN. LAws, c. 333, $\$ 16$ (1931). Allen v. Guarante, 253 Mass. 152, 148 N. E. 461 (1925). TENnEsSEE ANN. CODE, 9775 (1934).

${ }^{31}$ Iowa CODE ANN., 622.2 (1950). Searey v. Miller, 57 Iowa 613, 10 N. W. 912 (1881); Dedric v. Hopson, 62 Iowa 562, 17 N. W. 772 (1883); Stato v. Browning, 153 Iowa 37,133 N. W. 330 (1911). (All to the effect that religioug belief of a witness may be shown for the purpose of affecting his crodibility, but it must be by voluntary statement proviously made, and not by his examination on the stand.) Mississippi, without a portinent statute has declared that the eredibility of a witness may be attacked on grounds of religious dis. belief. Gambrell v. Mississippi, 92 Mliss. 728, 46 So. 138 (1908). NEBrAsKa Rev. STats., 25-1211 (1943). NEW MExICo Stats. ANN. $90-108$ (1941). And in Texas, Thronley v. State, 127 Tex. Crim. App. 583, 78 S. W. $2 d 601$ (1935). The witness replied to the trial court's question why she did not swear to God, but affirmed to tell the truth, that it was against her religion to swear. The Court of Criminal Appeals held that the lower court's inquiry was no error, as it was not sought to impeach her testimony by showing that sho did not bolieve in the existence of a Supreme Being. 
a discussion of the propriety of allowing impeachment of the witness's credibility on the same grounds. ${ }^{32}$

It might be said, however, that the opportunity of so discrediting a witness on this ground has been severely limited by judicial interpretation in Iowa, ${ }^{33}$ Texas, ${ }^{34}$ and possibly other states which apparently would inquire into religious disbelief.

\section{The Atheist as Juror}

Logically, any state which would disqualify a witness because of irreligion, would also be hesitant to admit one equally "afflicted" to jury duty. This disability would not weigh heavily upon the atheist-especially in light of lay opinion concerning the "bothersome nature" of being selected for jury duty. Occasionally, however, the possibility of impeaching a juror on these grounds would result in injustice if the trial-or indictment in case of a grand juror-had proceeded fairly up to the point of the allegation of the juror's incompetence. To prevent this from occurring some states have provided that a challenge may not be allowed for any reason after the juror has been sworn, unless it be for some cause which has happened since he was sworn. ${ }^{35}$

The question of a juror's disqualification on religious grounds has not been often raised, especially in the last century; some cases have been found which have discussed the problem nevertheless. ${ }^{36}$

\section{Dying Declarations of the Atheist}

In addition to those states which discredit the testimony of a witness, or disallow it altogether, and which would consequently allow impeachment or exclusion of dying declarations of the irreligious, a few states can be listed which would evidently allow

32 See the discussion in State v. Beal, supra, and beginning of the discussion in Part II, infra.

${ }^{33}$ Searcy v. Miller, 57 Iowa 613, 10 N. W. 912 (1881).

34 Thornley v. State, 127 Tex. Crim. App. 583, 78 S. W. $2 d 601$ (1935).

35 See State v. Davis, 80 N. C. 412 (1879).

sa IowA: State v. Jaekson, 156 Iowa 588, 137 N. W. 1034 (1912). (Belief in Supreme Being alone, enough.) MarYLaND CoNst., Declar. of Rights, Art. 36 (1867), and State v. Mercer, 101 Md. 535, 61 Atl. 220 (1905). (Belief in a Supreme Being, and divine punishment necessary.) NoRTH CarourNa and TENNESSEE: State $\nabla$. Luevy, 187 N. C. 581, 122 S. E. 386 (1924); State v. Davis, 80 N. C. 412 (1879). McClure v. State, 9 Tenn. 206 (1829). (Evidently belief in Supreme Being alone, enough, and not allowing impeachment on religious pretext after the juror is sworn.) 
impeachment of such declarations, but would not discriminate against an atheist as a witness. ${ }^{37}$

Two different lines of policy can be discerned in these decisions. One is similar to the objection to the atheistic witness: that is, the feeling that without a belief in a God who would punish in the hereafter-quite imminent in the case of a dying deelarant-for false and malicious statements, the words of the dying are not to be trusted. The other, and sounder line, is a judicial assumption of the presence of some degree of theism in most persons. When the declaration is made, if the declarant indulges in profane language evidencing an "irreverent state of mind," it is strong evidence that the declarant may not actually believe himself in such dire straits as he later proved to be. Consequently, less weight should be accorded a declaration which the declarant himself did not regard as a "dying" one.

\section{The Atheist and Public Office}

The final field of deprivation to be covered in this article is the denial of the right to hold public office. Eight states have constitutional provisions requiring belief in God in order to serve the state. ${ }^{38}$

This area seems to be completely unlitigated. By all odds most men who would seek public office, would be very shy to admit a disbelief which would prejudice them with a substantial portion of the electorate, and provide opposing eandidates with snch potent political fodder. But, on the other hand, these same constitutional disqualifications would also apply to the numerous non-elective offices in the administrative hierarchy of the modern day state, and

${ }^{37}$ CaIIFORNIA: People v. Lim Foon, 29 Cal. App. 270,155 Pac. 477 (1915). (In the court's words, "declaration of one wholly obtuse to religious convictions would be greatly impaired." ') InINoIs: Nordgron v. People, 211 Ill. 425 , 71 N. E. 1042 (1904); Tracy v. People, 97 Ill. 101 (1880). (Profane language held to be indication of an irreverent state of mind.) Mrssonrs: State $\nabla$. Rozell 225 S. W. 931 (Mo. Sup. Ct. 1020). (Credibility affected by testimony of dis. belief of God and future state of man after death.) Query the further application of this case as noted in McClollan v. Owons, 335 Mo. 884, 74 S. W. 2d 570 (1934).

${ }^{38}$ Arkansas Const., Art. 19, $\$ 1$ (1874). Miaryuand Const., Declar. of Rights, Art. 37 (1867). (Belief in the existence of God enlarged to requiro acknowledgmeut of a future state of rewards and punishments by statute: ANN. CoDE of Min., 1951, Art. 70, 9.) Mississippi Const, Art. 14, 265 (1890). Nortin Carolina Const., art. 6, \$8 (1868). Pennsyutania Const., Art. $1, \$ 4$ (1874). Sodth Carolina Const., Art. 9, $\$ 4$ (1870). Tennessee Constr., Art. 1, $\$ 2$ (1870). Texas Const., Art. $1, \$ 4$ (1876). 
one might think it strange that a conscientious appointee who was a religious non-believer has not contested disqualifying state constitutional provisions on Fourteenth Amendment grounds.

II

Assuming for the moment that our institutions $d o$ presuppose a Supreme Being, ${ }^{30}$ it is not readily apparent to this writer just why public officers must believe in a Supreme Being. From such a presupposition, it would follow that the state-being one of our most important of institutions-itself presupposes a Supreme Being. But unless we posit that an atheist is less ethical than a religious believer, should he in all cases be exclucled from public office? For if it is once conceded that atheists "in general" are equally ethical, they may with integrity serve a state which presupposes a Supreme Being. Further, it is suggested, that in the political affairs of a modern state, there are "fundamental beliefs" more relevant to the fulfllment of the public officer's tasks, than a belief in a Supreme Being. Beliefs such as "fair-play," "honesty," and "democracy," are more pertinent and equally illusive of definition.

INost states no longer discriminate against atheists in any sphere. This may be because of a realization of one of the basic undercurrents of American institutions as a whole, the realization that inquiry by a state into one's belief or disbelief in religion for any purpose is not to be tolerated. For a rather convincing argument can be made out to deny atheists oath-taling. It might be said that given two people, supposedly "equally ethical," about to undertake an "oath" -in the interest of the highest truthfulness or allegiance obtainable-should not more weight be accorded to that person who has an additional stimulus to truthfulness by his belief in God? $?^{40}$

But how much "belief"' is necessary? In some jurisdictions, notably Maryland, a belief in either present or future divine punishment in addition to belief in a God is necessary to qualify as a witness or juror. While in the same state, in addition to a belief in God, a public officer must acknowledge the certainty of divine punishment in the hereafter. In the modern, perhaps too sophisticated, world the word "theist," or even "Christian" em-

so Zorach จ. Clauson, 343 U. S. 306, 313 (1952).

${ }^{10}$ But cf. common-law theory of oath, Part I, supra, for argument at a earlier time against allowing atheistic witnesses to testify. 
braces all shades of belief from the transcendental God of Emerson to the fire and brimstone God of the camp-meeting. And belief in a hereafter includes such diverse interpretations as the Wrath of God executed in a flaming inferno, or a belief in a hereafter that would totally exclude a notion of divine punishment.

Is not the result of many of the statutes and constitutional provisions considered in this article a judicial prying into the conscience to determine religious belief? Jefferson spoke of similar inquiry as "Bribing a man with worldly honors to change ehurches by laying upon him an incapacity of being called to offices of trust and emolument unless he profess or renounce this or that religious opinion." $" \pm 1$

Can an argument be made that the United States Supreme Cour't might hold disabilities imposed upon atheists unconstitutional under the First Amendment via the Fourteenth? The controversy over the Court's historical analysis of the First Amendment ${ }^{22}$ in the recent church-state cases ${ }^{43}$ are beyond the scope of this article. This is an effort, rather, to discover the attitudes of the respective justices were the question presented. Further, since contemporary decisions will be rendered by the contemporary court, historical analysis of what the United States Supreme Court thought in the past, is avoided, although it may be remarked that the Court first stated judicially that the First Amendment was intended to erect a "wall of separation between Church and State," in 1878. ${ }^{44}$

Pronouncements of this nature have recently occurred in cases where atheism was involved only very incidentally. ${ }^{45}$ The cases to be considered, Everson, McCollum, and Zorach, all involved aid in some degree by a state to religion. The Everson ease-reimburse-

iI Statute of Religious Toleration, p. -

"See note 4, supra.

43 Everson v. Board of Education, 330 O. S. 1 (1947); Illinois ex rel. MeCollum v. Board of Education, 333 U. S. 203 (1948); Zorach v. Clauson, 343 U. S. 306 (1952).

${ }_{44}$ Reynolds v. United States, 98 U. S. 145, 164 (1878). (Statute proseribing bigamy was attacked as an infringement of religious liberty.)

${ }_{45}$ Mrs. McCollum is an atheist, or as she deseribes horself, "It [atheism] is too militant a term, however, and it also implies a more profound student of theology than I am. If I must have a tag, I believe that 'Humanist' would describe me more aceurately." MaCoLLUM, ONE WoMAN's FIaHT (1951) p. 11. Evidently, one of her purposes in bringing suit in Illinois v. Board of Education was to stop the social disapproval that her son Terry had been subjected to as he stood apart from "religious" children as denominated by the Clam. paign "released time" program. 
ment by the State of New Jersey to Roman Catholic parents of transportation expense incurred in delivering their children to Catholic schools; the McCollum ease-the use by religious bodies of public school classrooms and facilities in providing religious instruction; children who availed themselves of such instruction were "released" to attend the religious classes; the other children were required to stay in a sort of study room; the Zorach case-like IIcCollum except that the religious instruction was provided away from the school, not using school classrooms or facilities.

No comment will be made on the well-known holdings of those cases, except to remind the reader that the Everson case-although containing some of the strongest language concerning the impregnable wall between Church and State-held that the transportation reimbursement to parents whose children attended paroehial schools was not violative of the "establishment of religion" clause of the First Amendment; that the McCollum doctrine invalidated the "released time" program of the Illinois school; and that Zorach provided that New York's "dismissed time" religious instruction away from the public school was constitutional.

The thrce opinions, read together, show that Justice Black, while admitting that there can be no hostility of the state toward religion, and even acknowledging that Americans are a religious people, nevertheless states that the slightest aid by government to religion, any or all religion, would be to breach the "wall of separation" between Church and State (although query the actual result reached in the Everson case). He would award atheists equal freedom under the First Amendment that would be accorded religious believers. ${ }^{46}$ He was joined in these statements by Chief Justice

so Everson v. Board of Education, 330 U. S. 1 (1947):

First Amendment intended to include the same protection against governmental intrusion on religious liberty as the Virginia Statute of Toleration. Id. at 13.

"Neither [a state nor the Federal Government] can pass laws which aid one religion, aidd all religions, or prefer one religion over another. Neither can force... [a person] to profess a belief or disbelief in any religion. No person can be punished for entertaining or professing religious beliefs or disbeliefs ...." Id. at 15-16. "The First Amendment has erected a wall between church and state. That wall must be kept high and impregnable. ...' Id. at 18.

Illinois ex rel. McCollum v. Board of Education, 333 U. S. 203 (1948):

"A manifestation of such hostility [government hostility to religion or religious teaching] would be at war with our national tradition as embodied in the First Amendment's guaranty of the free exercise of religion. [But he goes on to say] For the First Amendment rests upon the premise that both religion 
Vinson, and Justices Reed, Douglas, and Clark in the Everson case; by Chief Justice Vinson, and Justices Douglas and Clark in the $M c C o l l u m$ case ; in Zorach he wrote for himself in dissent.

Justice Frankfurter also believes that the First Amendment was to secure complete and impregnable separation between religion and the state, and that the state may not in any way help religion. This wall between Church and State cannot be completely outlined in one opinion; it must be defined as the principle is appealed to from case to case. ${ }^{47}$ His views are shown in his subscription to the dissents of Justices Jackson and Rutledge (with Jackson and Burton in the latter) in the Everson case; his own concurrence, with Justices Jackson, Rutledge and Burton in the McCollum case; and his own, and agreement with Justice Jackson's, dissent in the Zorach case.

and governmont can best work to achieve their lofty aims if oach is left froe from the other within its rospective sphere. ..." Id at 211-212.

Zorach v. Clauson, 343 U. S. 306 (1952) :

Black substantially reiterates his position in the Everson and MICCollum decisions, and evidently acquiesces in Justice Douglas' proposition of our boing a religious people with institutions presupposing a Supreme Boing, but says that such was equally true when the First Amendment was framed, and when the Court, 8-1, invalidated the McCollum plan "on the promises that a stato can no more 'aid all religions' than it can aid one. ... For a state policy of aiding 'all religions' necessarily requires a governmental decision as to what constitutes 'a religion.'" Id. at 318 aud $\mathrm{fn}$. that page.

He goes on to warn that the Court's abandonment of governmental noutrality regarding religion "is all the more dangerous to liberty because of the Court's legal exaltation of the orthodox and its derogation of unbelievors." Id. at 318. "Under our system of religious freedom. ... The spiritual mind of man has ... . been free to believe, disbolieve, or doubt, without ropression, great or small by the heavy hand of government. ... B Before today, our judicial opinions have refrained from drawing invidious distinctions between those who believe in no religion and those who do believe. The First Amendment has lost much if the religious follower and the atheist are no longer to bo judicially regarded with equal justice under law.' Id. at 319-320.

47 Everson v. Board of Education, 330 U. S. 1 (1947):

See Jackson's and Rutledge's opinions, infra.

Illinois ex rel. MoCollum v. Board of Education, 333 U. S. 203 (1948):

Appeal to the principle of soparation of Church and State from caso to case: Ia. at 223 .

"Separation is a requirement to abstain from fusing functions of government and of religious sects, not merely to treat them all equally.' Id. at 227. "Separation means separation, not something less. Jefferson's metaphor in describing the relatien between Church and State speaks of a 'Wall of separation,' not of a fine line easily overstepped." Id. at 231.

Zorach จ. Clauson, 343 U. S. 306 (1952):

Element of "coercion" should have been allowed in evidence at the trial. And see Justice Jackson's opinion, infra. 
To Justice Reed, separation of Church and State may not be determined by a figure of speech: "Wall of separation between church and state." He would allow some degree of aid to religion, and would disagree with a constitutional interpretation which did not include cognizance of the basic religiosity of the American people. Although he concurred with Justice Black in the Everson decision, his views are shown in his dissent in $M c C o l l u m$, and in his adhering to Justice Douglas' opinion in Zorach.48

Justice Douglas, although postulating that the government may not use secular institutions to force religion on any person, sees complete independence between Church and State as necessarily predicated on hostility. He evidently feels that some form of gorernmental "helping hand" should be lent to religious activity. Even though he concurred with Justice Black in the Everson and ILCCollum decisions, his position is clearly stated in his majority opinion in the Zorach case, Chief Justice Vinson, and Justices Reed, Burton, Clark, and Minton concurring, in his statement that "our institutions presuppose a Supreme Being." 449

\&8 Everson v. Board of Education, 330 U. S. 1 (1947):

See Justice Black's opinion, supra.

Illinois ex rel. MeCollum v. Board of Education, 333 U. S. 203 (1948) :

"A rule of law should not be drawn from a figure of speech." $I d$ at 247.

Criticizing the majority's historical interpretation of the meaning of the First Amendment: “Thus, Mr. Madison's approval of Mr. Jefferson's report as Reetor [of the University of Virginia, concerning religious establishment at the University] gives .... a clearer indication of his views on the constitutionality of religious education in public schools than his general statements on a different subject [in the Memorial and Remonstrance Against Religious Assessments] ."Id. at 248.

He then lists examples of Federal "aid" to religion. Id. at 253-254.

Reed concludes his opinion, saying, "Devotion to the great principle of religious liberty should not lead us into a rigid interpretation of the constitutional guarantee that conflicts with accepted habits of our people." Id. at 256.

Zorach v. Clauson, 343 U. S. 306 (1952):

See Justice Douglas' opinion, infra.

to Iverson v. Board of Education, 330 U. S. 1 (1947):

See Justice Black's opinion, supra.

Illinois ex rel. MeCollum v. Board of Education, 333 U. S. 203 (1948).

See Justice Black's opinion, supra.

Zorach $\nabla$. Clauson, 343 U. S. 306 (1952).

"... . 'so help me God' in our courtroom oath ... all ... reference to the Almighty that run through our laws, our public rituals, our ceremonies would be flouting the First Amendment [if the wall of separation be complete]. ... A fastidious atheist or agnostic could even object to the supplication with which the Court opens each session: 'God save the United States and this Honorable Court." "' Id. at 313.

"The First Amendment, however, does not say that in every and all re- 
Justice Jackson would let the state have no contact with religion. The wall he builds seems the staunchest of them all. There can be no governmental aid whatsoever; irreligion and atheists may not be impeached for their unbelief by any governmental agency; in affixing the label of "religion" the government is taking the first step toward deciding which is the "right" religion. He denies that there is hostility toward religion if the government remains completely neutral. He spoke thus in his dissent with Justice Frankfurter in Everson; in his own, and his subscription to Justice Frankfurter's, concurring opinion in McCollum; and in his dissent with Frankfurter agreeing in Zorach. ${ }^{50}$

spects there shall be a separation of Church and State. Rather, it studiously defines the manner, the specific ways, in which there shall bo no concern or union or dependency one on the other. That is the common sense of the matter. Otherwise, the state and religion would be aliens to each other-hostile, suspicious, and even unfriendly." Id. at 312 .

"... To hold that it [the government] may not [cooperate with religious authorities] would be to find in the Constitution a requiroment that the government show a callous indifference to religious groups. That would bo preferring those who believe in no religion over those who do believe." Id. at 313-314.

But, the "Government may not use secular institutions to force one or some religion on any person. But we find no constitutional requirement which makes it necessary for government to be hostile to religion and to throw its weight against efforts to widen the effective scope of religious influence." Id. at 314.

"Our individual preferences ... are not the constitutional standard. The Constitutional standard is the separation of Church and State." Ibid.

to Everson v. Board of Education, 330 U. S. 1 (1947):

The purpose of the First Amendment was to take "every form of propagation of religion out of the realm of things which could directly or indirectly be made public business and thereby be support in whole or in part at taxpayer's expense." Id. at 26.

And see his concurrence with Justice Rutledge's opinion: Id. at 31.58.

nlinois ex rel. McCollum v. Board of Edueation, 333 U. S. 203 (1948):

Doubting the court's jurisdiction: The Court can interfere with a school board only when there is an invasion of a personal liberty or proporty right protected by the Federal Constitution: "Ordinarily, this will come about in either of two ways: First: When a person is required to submit to some religious rite or instruction or is deprived or threatenod with deprivation of his freedoms for resistiug such unconstitutional requirement. ..." Id. at 232 .

Speaking of Mrs. MeCollum: "The plaintiff, as she has every right to be, is an avowed atheist." Id. at 234 .

Concerning the Court's view of deciding where the secular ends and sectarian begins in education: "It is a matter on which we can find no law but our own prepossessions."' Id. at 238

Zorach v. Clauson, 343 U. S. 306 (1952):

"My evangelistic brethren confuse an objection to compulsion with an objection to religion. It is possible to hold a faith with enough confldence to believe that what should be rendered to God does not need to be collected by Caesar. 
May an atheist witness or prospective office holder invoke the First Amendment's protection of religious freedom? Despite some language in the Zorach case, it is submitted that a religious disbeliever might have considerable success with that proposition. Of course, the resulting constitutional guarantee would be freedom from, rather than of, religion. But that, only in a sense. Governmental protection-through a fire or police department-would result in little deprivation of liberty or property of the atheist. But a disbeliever who is a plaintiff in cause, and denied the right to testify in his own behalf, has experienced severe deprivation.

And, even granted the proposition that "we are a religious people whose institutions presuppose a Supreme Being," must it necessarily follow that the religious disbeliever can be deprived of civil rights? "Majority rule and minority rights" is a phrase which has characterized First Amendment freedoms as a whole. Minority rights, the right to disagree fundamentally with what might be thought to be the major premise of majority rule, seems secure under our constitution. Beliefs and expression may be curtailed only if they offer a danger-clear and present, or something less-to the society made up of the majority. ${ }^{51}$

It is not believed that such a danger could be demonstrated by mere disbelief in God. A witness testifying in a court, or an aspirant for public office, is bound to his duty to speak truthfully, or serve honestly, by primary considerations other than those predicated on a belief in God-sad though disbelief may be. And even in the philosophical realm, the impact of humanism has reached down in society far below the intellectual to touch men who have not heard of the word.

A people can be basically religious, and their primary law or constitution can still afford equal right to the irreligious.

It is true that disabilities imposed upon atheists have occurred only infrequently in the last century, and that some states which

\footnotetext{
"The day that this country ceases to be free for irreligion it will cease to be free for religion-except for the sect that can win political power." Id. at 325.

"The wall which the Court was professing to erect between Church and State has become even more warped and twisted than I expected. Today's judgment will be more interesting to students of psychology and of the judicial processes than to students of constitutional law." Ibid.

${ }^{61}$ Cantwell v. Connecticut, 310 U. S. 296 (1940); Davis v. Beason, 133 U. S. 333 (1890); Black and Douglas, JJ., concurring in West Virginia State Board of Education v. Barnette, 319 U. S. 624 (1943).
} 
ostensibly impose such disability today, might reverse previous practice. $^{52}$

But the existence of state constitutional provisions, statutes, and cases act, in a way, as a "previous restraint" on the atheists in those jurisdictions today. The United States Supreme Court appears amenable to the proposition that these state disabilities are contrary to the Federal Constitution and, more specifically, to the First Amendment. A test case may be appropriate.

${ }^{32}$ See discussion of North Carolina's pronouncements on the non-roligious witness as diseussed in Part I, supra. 